\title{
Cost-Utility Analysis of Heberprot-P as an Add-on Therapy to Good Wound Care for Patients in Slovakia with Advanced Diabetic Foot Ulcer
}

\author{
Tomas Tesar ${ }^{1 *}$, Laszlo Szilberhorn ${ }^{2,3}$, Bertalan Nemeth ${ }^{2}$, Balazs Nagy ${ }^{2,3}$, Martin Wawruch ${ }^{4}$ \\ and Zoltan Kalo ${ }^{2,3}$ \\ ${ }^{1}$ Department of Organisation and Management in Pharmacy, Faculty of Pharmacy in Bratislava, Comenius University, \\ Bratislava, Slovakia, ${ }^{2}$ Syreon Research Institute, Budapest, Hungary, ${ }^{3}$ Department of Health Policy and Health Economics, \\ Eötvös Loránd University (ELTE), Budapest, Hungary, ${ }^{4}$ Faculty of Medicine in Bratislava, Institute of Pharmacology and \\ Clinical Pharmacology, Comenius University, Bratislava, Slovakia
}

\section{OPEN ACCESS}

Edited by:

Brian Godman,

Karolinska Institute (KI), Sweden

Reviewed by:

Robert L. Lins,

Retired, Antwerpen, Belgium

Domenico Criscuolo,

Genovax S.r.l., Italy

Antony Paul Martin,

University of Liverpool,

United Kingdom

*Correspondence:

Tomas Tesar

tesar@fpharm.uniba.sk

Specialty section:

This article was submitted to Pharmaceutical Medicine and

Outcomes Research,

a section of the journal

Frontiers in Pharmacology

Received: 20 October 2017 Accepted: 13 December 2017 Published: 22 December 2017

Citation:

Tesar T, Szilberhorn L, Nemeth B, Nagy B, Wawruch M and Kalo Z

(2017) Cost-Utility Analysis of Heberprot-P as an Add-on Therapy to Good Wound Care for Patients in

Slovakia with Advanced Diabetic Foot Ulcer. Front. Pharmacol. 8:946. doi: 10.3389/fphar.2017.00946
Objectives:To explore whether Heberprot-P (an epidermal growth factor) is a cost-effective option for the treatment of advanced diabetic foot ulcer as an add-on therapy to good wound care (GWC) in Slovakia from the perspective of health care payers.

Methods: A Markov model was constructed to compare the costs and effects of Heberprot-P plus GWC to those of GWC alone from the perspective of health care payers. The 52-week clinical trial period was extended to 5- and 10-year time horizons. Transition probabilities were calculated based on a previous clinical trial of Heberprot, utility values were derived from the scientific literature, and cost vectors were collected from the General Health Insurance Fund database in Slovakia. A one-way deterministic sensitivity analysis was employed to explore the influence of uncertainty for each input parameter on the incremental cost-effectiveness ratio (ICER).

Results: Based on the ICER threshold of $€ 30,030$ per quality-adjusted life year (QALY) recommended by the Slovak Ministry of Health, Heberprot-P therapy plus GWC is not a cost-effective alternative to GWC alone over a 10-year time horizon. The ICER increases if a longer time horizon is applied, as the incremental costs are similar, but the aggregated utility gain from avoided amputation is lower. Based on the sensitivity analysis, the utility multiplier for the health state "no ulcer after small amputation" had the most impact on the ICER; however, the model was robust to changes in all input parameters.

Conclusions: Heberprot-P, as an add-on therapy to GWC in the treatment of advanced diabetic foot ulcer, is not a cost-effective alternative to GWC alone. However, if the unit cost of Heberprot-P were to be reduced to $<€ 273$, its ICER would be $<€ 30,030$.

Keywords: decision making, insurance, health, health policy, Slovakia, reimbursement mechanisms

\section{INTRODUCTION}

Core principles of the Slovak health care system include obligatory public insurance, general coverage, and an essential benefits package. Furthermore, the Slovak insurance model promotes competitiveness based on selective contracts with health care providers and flexibility in health services pricing (Smatana et al., 2016). 
Davis et al. (2006) highlighted that diabetes mellitus is a noncommunicable endocrine disease that leads to serious health complications, such as foot ulcers, and it has a globally increasing incidence. The incidence of lower-extremity amputations ranges from 2.1 to 13.7 per 1000 cases of diabetes (Bartus and Margolis, 2004).

Heberprot-P is a recombinant human epidermal growth factor. It is intended as an add-on therapy to conventional treatment for diabetic patients with neuropathic and ischemic ulcers, at stages 3 and 4 of the Wagner Ulcer Grade Classification System, with a wound area $>1 \mathrm{~cm}^{2}$. Heberprot-P stimulates the formation of useful granulation tissue, which allows healing by secondary intention or following a skin autograft, as demonstrated in several clinical studies (Fernández-Montequín et al., 2009; Berlanga et al., 2013).

The Slovak Ministry of Health has stated that, despite Heberprot-P not having received marketing authorization from the European Medicines Agency or the Slovak marketing authorization authority (the Slovak Institute for Drug Control), it can be administered to patients in Slovakia. This is an exception to the Slovak legislative Act No. 362/2011, which declares that only medicinal products with marketing authorization can be used for treatment.

Cuba has offered to pay its historic debt to the Slovak Republic using the medicinal products that it can spare, including Heberprot-P. The debt is largely a legacy of business ties between Cuba and Czechoslovakia, which split into the Slovak Republic and the Czech Republic in 1993, 4 years after the end of four decades of communist rule.

In the Slovak Republic, drug reimbursement requires stringent criteria to be met, which involves the evaluation of clinical evidence along with cost evidence, full transparency, and the possibility of a formal appeal (Barnieh et al., 2014). Act No. 363/2011 Coll. (Ministry of Health, 2011a) defines two thresholds (" $\lambda_{1}$ " and " $\lambda_{2}$ ") used by the Slovak Ministry of Health in the reimbursement decision-making process. The lower threshold $\left(\lambda_{1}\right)$ is 24 times the average monthly salary, and the upper threshold $\left(\lambda_{2}\right)$ is 35 times the average monthly salary (Ministry of Health, 2011a). When the incremental cost per quality-adjusted life year (QALY) is lower than or equal to $\lambda_{1}$, the drug is fully or partially reimbursed. For cases in which the incremental costs per QALY are higher than $\lambda_{1}$, but do not exceed $\lambda_{2}$, the drug is reimbursed with conditions (Ministry of Health, 2011a).

Two options have been considered for the public financing of Heberprot-P for Slovak patients. The first option is to reimburse this medicinal product using health insurance funds. Slovakia has a pluralistic system of health insurance companies, with three health insurance companies operating: the state-owned General Health Insurance Company ("V̌̌eobecná zdravotná poist'ovňa”), and the private Trust ("Dôvera") and Union, which covered $63.31 \%, 27.92 \%$, and $8.77 \%$ of Slovak population, respectively, in 2015 (Health Care Surveillance Authority, 2016). The second option is to cover Heberprot-P based on Cuba's debt repayment to Slovakia.

The Pharmaceutical Faculty of Comenius University in Bratislava, Slovakia, and the Syreon Research Institute in Budapest, Hungary, were asked by the Slovak Ministry of Health to perform a pharmacoeconomic study concerning Heberprot$\mathrm{P}$ within the settings of the Slovak health care system. The research question concerned whether Heberprot-P is a costeffective option for treatment of advanced diabetic foot ulcer (DFU) as an add-on therapy to good wound care (GWC) in Slovakia.

\section{MATERIALS AND METHODS}

A Markov model was constructed to compare the costs and effects of Heberprot-P plus GWC to those of GWC alone over a 52-week period based on clinical trial data (FernándezMontequín et al., 2009). Previous Markov models applied one-year time horizon in the economic evaluation of new technologies in diabetic foot ulcer (Redekop et al., 2003; Gilligan et al., 2015; Guest et al., 2017). According to the local methodological guidelines time horizon of economic evaluations should be long enough to take into account all important clinical outcomes and costs (Ministry of Health, 2011b). As quality of life benefit of avoided amputation stays constant over time, time horizon of the model was extended to capture these benefits over

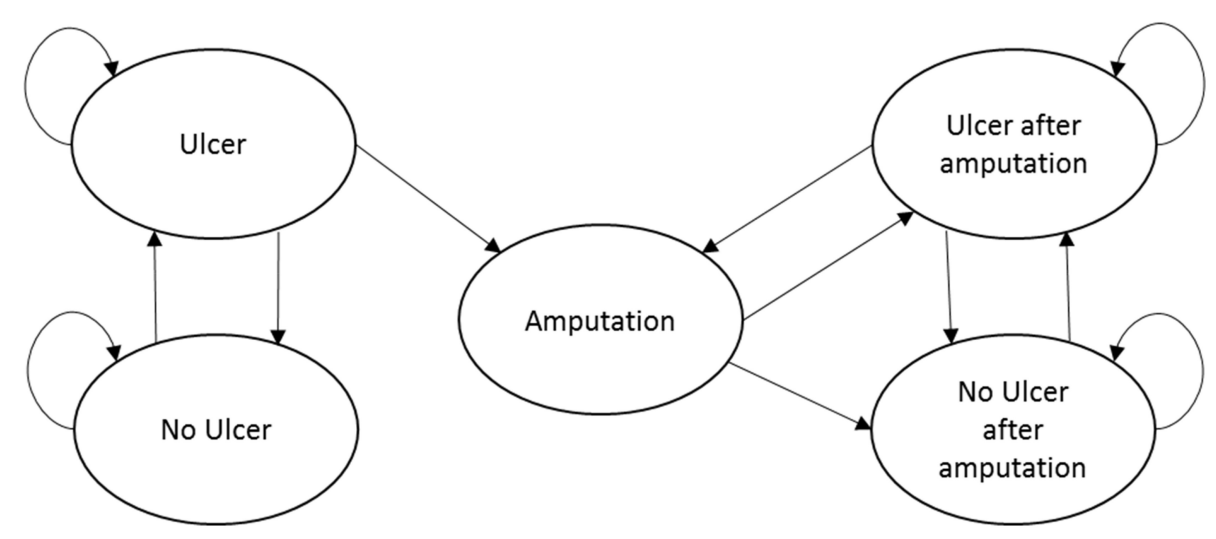

FIGURE 1 | Transition routes of the patients in the Markov model. 
10 years. In addition, a scenario analysis involving a shorter (i.e., five-year) time horizon was also carried out. A one-week cycle length was chosen, following the structure of the clinical trial data (Fernández-Montequín et al., 2009). According to the Slovak methodological guidelines for economic evaluations, a health care perspective (i.e., third-party payers' perspective) was applied (Ministry of Health, 2011b). A 5\% discount rate was applied to both the health gains and costs (Ministry of Health, 2011b).

The Markov model included five mutually exclusive health states: (1) no ulcer; (2) ulcer (the starting health state for all patients); (3) amputation; (4) no ulcer after amputation; and (5) ulcer after amputation (see Figure 1). We assumed that Heberprot-P has no direct or indirect influence on mortality, and the age- and disease-related mortality of the patients remain constant during the 10-year modeling time horizon. Consequently, we simplified the model structure by excluding death from the health states.

Deep ulcer-related infections (such as osteomyelitis) or gangrene are significant complications of DFU. However, the clinical trial report had no detailed information about these complications; therefore, we did not separate these complications into Markov health states. We assumed that $10 \%$ of active ulcers are infected, based on a previous modeling study (Redekop et al., 2003).

\section{Transition Probabilities}

In the clinical trial, efficacy results were reported at two, eight, and 52 weeks. Unfortunately, at 2 and 8 weeks, the key efficacy outcome was $>50$ and $>75 \%$ granulation, respectively. Therefore, no information was available about how many patients had a fully-healed ulcer (i.e., "no ulcer") at these time points. Consequently, we calibrated weekly transition probabilities to reflect the 52-week efficacy parameters (Fernández-Montequín et al., 2009), including: (1) ulcer closure; (2) amputation; and (3) ulcer recurrence.

We assumed that at 8 weeks, Heberprot-P therapy had no further benefit beyond the 52-week observation period, so between years one and 10, the transition probabilities of the GWC arm were applied to both arms. We also assumed that ulcer recurrence and healing rates were equal in both arms after amputation. Recurrence in the GWC arm was estimated by dividing the two recurrent cases by the total population in both arms (108 patients).

\section{Costs}

Cost data for the health states used in the model were provided by the Slovak Ministry of Health, which retrieved them from the database of the largest (63.31\% of the population) Slovak health insurance company, General Health Insurance Company. The Heberprot-P treatment cost was calculated based on the unit cost per injection multiplied by the number of units needed per week and the length of therapy (in weeks).

\section{Utilities}

The utilities associated with the health states (see Table 1) were based on a published research paper that used the time tradeoff methodology (Redekop et al., 2004). We assumed, based on the database of the General Health Insurance Fund, that 50\% of minor amputations are toe amputations and the remaining $50 \%$ are foot amputations, while all major amputations are leg amputations. Annually, there are 500-600 major amputations (legs) and 3,000-5,000 small amputations (part of feet or toes) for diabetic patients in Slovakia.

A one-way deterministic sensitivity analysis was employed to explore the influence of uncertainty for each input parameter on the incremental cost-effectiveness ratio (ICER). All the parameters were changed by $\pm 10 \%$.

TABLE 1 | Utilities associated with health states.

\begin{tabular}{|c|c|c|}
\hline Health state & Utility & Source \\
\hline $\begin{array}{l}\text { Diabetic patient with no ulcer } \\
\text { (reference value) }\end{array}$ & 0.840 & Redekop et al. (2004) \\
\hline Ulcer (multiplier) & 0.890 & Redekop et al. (2004) \\
\hline Infected ulcer (multiplier) & 0.820 & Redekop et al. (2004) \\
\hline $\begin{array}{l}\text { After small amputation, no ulcer } \\
\text { (multiplier) }\end{array}$ & 0.830 & $\begin{array}{l}\text { Mean of patients with toe } \\
\text { or foot amputation, } \\
\text { based on Redekop et al. } \\
(2004)\end{array}$ \\
\hline $\begin{array}{l}\text { After leg amputation, no ulcer } \\
\text { (multiplier) }\end{array}$ & 0.730 & Redekop et al. (2004) \\
\hline $\begin{array}{l}\text { Acute 30-day post-amputation period } \\
\text { (multiplier) }\end{array}$ & 0.500 & Assumption \\
\hline $\begin{array}{l}\text { Infected ulcer after small amputation } \\
\text { (multiplier) }\end{array}$ & 0.715 & $\begin{array}{l}\text { Mean of patients with toe } \\
\text { or foot amputation and } \\
\text { infected ulcer, based on } \\
\text { Redekop et al. (2004) }\end{array}$ \\
\hline $\begin{array}{l}\text { Infected ulcer after leg amputation } \\
\text { (multiplier) }\end{array}$ & 0.620 & $\begin{array}{l}\text { One leg amputated and } \\
\text { active infected ulcer, } \\
\text { based on Redekop et al. } \\
(2004)\end{array}$ \\
\hline $\begin{array}{l}\text { Proportion of infected ulcers out of all } \\
\text { ulcers }\end{array}$ & $10.00 \%$ & $\begin{array}{l}\text { Assumption based on } \\
\text { Redekop et al. (2003) }\end{array}$ \\
\hline $\begin{array}{l}\text { Proportion of leg amputations out of } \\
\text { all amputations }\end{array}$ & $12.08 \%$ & $\begin{array}{l}\text { Slovak Ministry of Health } \\
\text { data }\end{array}$ \\
\hline
\end{tabular}

TABLE 2 | Incremental cost-effectiveness ratio (ICER) based on a 10-year time horizon.

\begin{tabular}{lccc}
\hline & Heberprot-P plus GWC & GWC & Difference \\
\hline QALY & 6.5610 & 6.3901 & 0.1709 \\
Cost $(€)$ & 130,675 & 115,235 & 15,440 \\
ICER (€ per QALY) & & 90,344 &
\end{tabular}

QALY, quality-adjusted life year; ICER, incremental cost-effectiveness ratio; GWC, good wound care.

TABLE 3 | Incremental cost-effectiveness ratio (ICER) based on a five-year time horizon.

\begin{tabular}{lccc}
\hline & Heberprot-P plus GWC & GWC & Difference \\
\hline QALY & 3.6784 & 3.5814 & 0.0970 \\
Cost $(€)$ & 81,167 & 65,727 & 15,440
\end{tabular}

ICER (€ per QALY) 
Utility of after small amputation no ulcer (multiplier)

Transition prob.: Ulcer to No ulcer Placebo arm

Transition prob.: Ulcer to No ulcer Heberprot-P arm

Transition prob.: Ulcer to Amputation Placebo arm

Heberprot $75 \mu \mathrm{g}$ price per unit

Heberprot $75 \mu \mathrm{g}$ unit per week

Utility of no ulcer (reference value)

Utility of ulcer (multiplier)

Transition prob.: Ulcer to Ulcer Heberprot-P arm

Transition prob.: Ulcer to Amputation Heberprot-P arm

Length of Heberprot $75 \mu \mathrm{g}$ therapy (weeks)

Utility of after leg amputation no ulcer (multiplier)

Transition prob.: Ulcer to Ulcer Placebo arm

Monthly cost of ulcer

Monthly cost of healed ulcer

$+10 \%=-10 \%$

110000130000150000170000190000210000230000250000

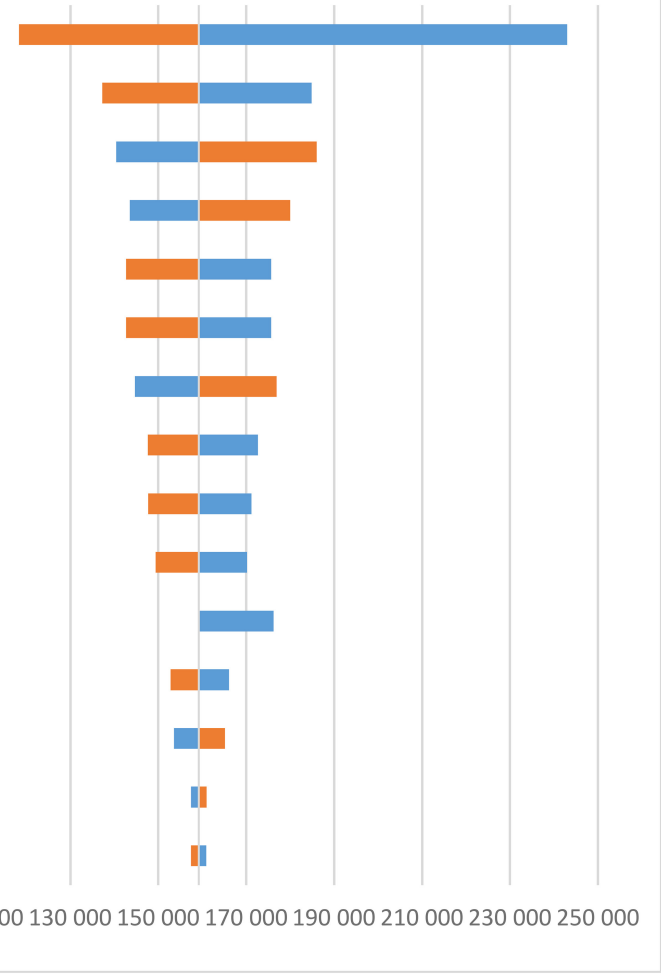

FIGURE 2 | Results of the deterministic sensitivity analysis (5-year time horizon) in $€$.

Probabilistic sensitivity analysis is not part of the routine economic evaluation in Slovakia (Ministry of Health, 2011b).

\section{RESULTS}

Over a 10-year time horizon, Heberprot-P generated a QALY gain of 0.1709 at an incremental cost of $€ 15,440$ (see Table 2).

The ICER worsened when a shorter time horizon was applied, as the incremental costs remained similar, but the aggregated utility gain from avoided amputation was lower (see Table 3 ).

Based on the sensitivity analysis, the utility multiplier for the health state "no ulcer after small amputation" had the most impact on the ICER. However, the model was robust to changes in all input parameters (i.e., the conclusion did not change when the input parameters were each changed by $\pm 10 \%$ ) (see Figures 2 and 3 ).

The results of this pharmacoeconomic study of Heberprot-P were validated by the Slovak Ministry of Finance.

\section{DISCUSSION}

Kaló et al. (2008) identified a number of potentially costineffective medicines that were being reimbursed prior to 2008 in the Slovak Republic. Since 2011, economic criteria have been applied to pharmaceutical pricing and reimbursement decisions, with explicit thresholds defined by Slovak legislation. Consequently, funds allocated to new medicines reflect opportunity costs in the Slovak health care system (Tesar et al., 2017).

Act No. 363/2011, Coll. (Ministry of Health, 2011a) mandates that pharmacoeconomic reports be produced for medicinal product reimbursement decision-making processes. Moreover, the Ministry of Health Decree No. 422/2011 (Ministry of Health, 2011b) stipulates that "pharmaceutical reimbursement decisions must be substantiated with pharmacoeconomic analyses."

In 2016, drugs with an ICER <€20.592 per QALY (lower threshold, $\lambda_{1}$ ) were eligible for reimbursement from the public health insurance funds, while drugs with an ICER of $€ 20.592-30.030$ per QALY (upper threshold, $\lambda_{2}$ ) could be conditionally reimbursed from these funds. Given the available patient access schemes in Slovakia, Van Wilder et al. (2015) argued that the ICER thresholds (i.e., the thresholds for incremental costs per QALY) provide a cost-effectiveness assessment tool for drugs rather than a reimbursement-exclusion regulation.

Foot ulceration is a serious complication of diabetes mellitus that is associated with an increased risk of amputation. Based on the upper ICER threshold $\left(\lambda_{2}, € 30,030\right)$ set by the Slovak Ministry of Health, Heberprot-P therapy plus GWC is not a cost-effective alternative to GWC alone based on a 10-year time 


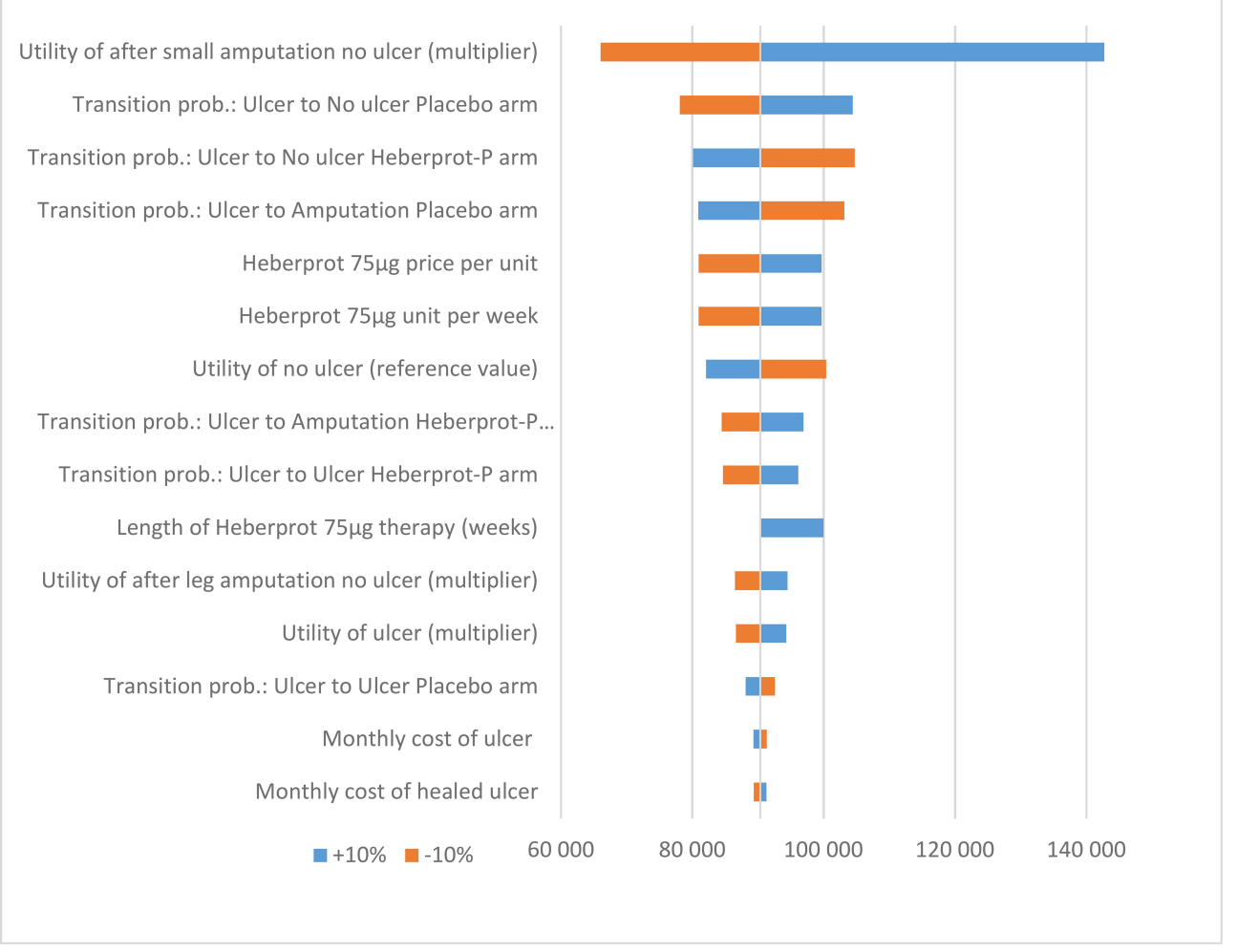

FIGURE 3 | Results of the deterministic sensitivity analysis (10-year time horizon) in $€$.

horizon. If the unit cost of Heberprot-P were to be reduced to $<€ 273$, its ICER would be $<€ 30,030$. Based on this study, it has been decided that Heberprot-P will not be reimbursed from the Slovak health insurance funds. Instead, Heberprot-P can be administered to patients in Slovakia, and the medicine will be provided by Cuba, as part of its debt repayment to Slovakia.

Cost-effectiveness of Heberprot-P has never been presented in any previous publications. However, generalizability of main conclusions is limited. Heberprot-P has not been evaluated by the European Medicines Agency, therefore high level uncertainty related to clinical effectiveness and safety of Heberprot-P need to be emphasized. In addition, heterogeneity of good wound care in

\section{REFERENCES}

Barnieh, L., Manns, B., Harris, A., Blom, M., Donaldson, C., Klarenbach, S., et al. (2014). A synthesis of drug reimbursement decision-making processes in organisation for economic co-operation and development countries. Value Health 17, 98-108. doi: 10.1016/j.jval.2013.10.008

Bartus, C. L., and Margolis, D. J. (2004). Reducing the incidence of foot ulceration and amputation in diabetes. Curr. Diab. Rep. 4, 413-418. doi: 10.1007/s11892-004-0049-x

Berlanga, J., Fernández, J., López, E., López, P., Del Río, A., Valenzuela, C., et al. (2013). Heberprot-P: a novel product for treating advanced diabetic foot ulcer. MEDICC Rev. 15, 11-15. doi: 10.1590/S1555-79602013000100004

Davis, W., Norman, P., Bruce, D., and Davis, T. (2006). Predictors, consequences and cost of diabetes-related lower extremity amputation complicating type different countries or regions represents an important limitation in the transferability of results to other jurisdictions.

\section{AUTHOR CONTRIBUTIONS}

TT, LS, BeN, BaN, MW, and ZK conceived the conception and design of the study. TT and MW contributed in acquisition of data. LS, BeN, BaN, and $\mathrm{ZK}$ carried out the data management and pharmacoeconomic modeling. TT prepared the draft of the manuscript. All authors contributed to editing the manuscript and the approved final version was submitted for publication.
2 diabetes: the Fremantle Diabetes Study. Diabetologia 49, 2634-2641. doi: 10.1007/s00125-006-0431-0

Fernández-Montequín, J., Valenzuela-Silva, C., Díaz, O., Savigne, W., SanchoSoutelo, N., Rivero-Fernández, F., et al. (2009). Intra-lesional injections of recombinant human epidermal growth factor promote granulation and healing in advanced diabetic foot ulcers: multicenter, randomised, placebo-controlled, double-blind study. Int. Wound J. 6, 432-443. doi: 10.1111/j.1742-481X.2009.00641.x

Gilligan, A. M., Waycaster, C. R., and Motley, T. A. (2015). Cost-effectiveness of becaplermin gel on wound healing of diabetic foot ulcers. Wound Repair Regen. 23, 353-360. doi: 10.1111/wrr.12285

Guest, J. F., Weidlich, D., Singh, H., La Fontaine, J., and Garret,t, A., Abularrage, C. J., Waycaster, C. R. (2017). Cost-effectiveness of using adjunctive porcine small intestine submucosa tri-layer matrix compared with standard care 
in managing diabetic foot ulcers in the US. J. Wound Care 2, S12-S24. doi: 10.12968/jowc.2017.26.Sup1.S12

Health Care Surveillance Authority (2016). [Report on the Status of Provision of Public Health Insurance during 2015] Správa o stave vykonávania verejného zdravotného poistenia za rok 2015. Úrad pre dohlad nad zdravotnou starostlivostou, Vestník 11/2016. Available online at: http://www.udzs-sk. sk/documents/14214/19424/VE_10_2015_Sprava_VZP_2014.pdf/c2a32c3ea50b-404f-941f-4a3fe189083f (Accessed Oct 18, 2017).

Kaló, Z., Docteur, E., and Moïse, P. (2008). Pharmaceutical pricing and reimbursement policies in Slovakia. OECD Health Working Papers 31, 1-54. doi: $10.1787 / 244264621247$

Ministry of Health (2011a). [Act No. 363/2011 Coll. On the Scope and Conditions of Payments for Medicines, Medical Devices and Dietetic Foods from Public Health Insurance and Amending Certain Acts, as Amended] Zákon č. 363/2011 Z. z. o Rozsahu a Podmienkach úhrady Liekov, Zdravotníckych Pomôcok a Dietetických Potravín na Základe Verejného Zdravotného Poistenia a o Zmene a Doplnení Niektorých Zákonov. Available online at: http://www.zakonypreludi. sk/zz/2011-363 (Accessed Oct 18, 2017).

Ministry of Health (2011b). [Decree No. 422/2011 of the Ministry of Health of the Slovak Republic on the Details of the Pharmacoeconomic Analysis of Medicine] Vyhláška č. 422/2011 MZ SR o Podrobnostiach Farmako-Ekonomického Rozboru Lieku. Available online at: http://www.zakonypreludi.sk/zz/2011-422 (Accessed Oct 18, 2017).

Redekop, W., McDonnell, J., Verboom, P., Lovas, K., and Kalo, Z. (2003). The costeffectiveness of Apligraf treatment of diabetic foot ulcers. Pharmacoeconomics 21, 1171-1183. doi: 10.2165/00019053-200321160-00003
Redekop, W., Stolk, E., Kok, E., Lovas, K., Kalo, Z., and Busschbach, J. (2004). Diabetic foot ulcers and amputations: estimates of health utility for use in cost-effectiveness analyses of new treatments. Diabetes Metab. 30, 549-556.

Smatana, M., PaŽitný, P., Kandilaki, D., Laktišová, M., Sedláková, D., Palušková, M., et al. (2016). Slovakia: health system review. Health Syst. Transit. 18, 1-210.

Tesar, T., Hloska, A., Wawruch, M., Lehocka, L., Snopkova, M., and Masarykova, L. (2017). Introduction of health technology assessment for medicines in Slovakia. Int. J. Technol. Assess. Health Care 33, 345-349. doi: 10.1017/S026646231700006X

Van Wilder, P., Mabilia, V., Kuipers Cavaco, Y., and McGuinn, J. (2015). Towards a Harmonised EU Assessment of the Added Therapeutic Value of Medicines. Study of the ENVI Committee. Available online at: http://www.europarl. europa.eu/RegData/etudes/STUD/2015/542219/IPOL_STU(2015)542219_EN. pdf (Accessed Oct 18, 2017).

Conflict of Interest Statement: The authors declare that the research was conducted in the absence of any commercial or financial relationships that could be construed as a potential conflict of interest.

Copyright (c) 2017 Tesar, Szilberhorn, Nemeth, Nagy, Wawruch and Kalo. This is an open-access article distributed under the terms of the Creative Commons Attribution License (CC BY). The use, distribution or reproduction in other forums is permitted, provided the original author(s) or licensor are credited and that the original publication in this journal is cited, in accordance with accepted academic practice. No use, distribution or reproduction is permitted which does not comply with these terms. 